\title{
C1q enhances cone photoreceptor survival in a mouse model of autosomal recessive retinitis pigmentosa
}

\author{
Marian M Humphries ${ }^{\star, 1,4}$, Paul F Kenna ${ }^{1,2,4}$, Matthew Campbell ${ }^{1}$, Lawrence CS Tam ${ }^{1}$, Anh TH Nguyen ${ }^{1}$, \\ G Jane Farrar ${ }^{1}$, Marina Botto ${ }^{3}$, Anna Sophia Kiang ${ }^{1}$ and Peter Humphries ${ }^{1}$
}

Retinitis pigmentosa (RP) is a degenerative retinal disease involving progressive loss of rod and cone photoreceptor function. It represents the most common form of registered blindness among the working aged populations of developed countries. Given the immense genetic heterogeneity associated with this disease, parameters influencing cone photoreceptor survival (preservation of daytime vision) that are independent of primary mutations are exceedingly important to identify from a therapeutic standpoint. Here we identify $\mathrm{Clq}$, the primary component of the classical complement pathway, as a cone photoreceptor neuronal survival factor.

European Journal of Human Genetics (2012) 20,64-68; doi:10.1038/ejhg.2011.151; published online 24 August 2011

Keywords: C1qa; C3; retinopathy; retinitis pigmentosa; complement; cone photoreceptors

\section{INTRODUCTION}

Hereditary retinopathies, prominent among which is retinitis pigmentosa $(\mathrm{RP})$, conditions involving progressive death of photoreceptors are amongst the most genetically heterogeneous of any group of mendelian conditions. Including Leber's congenital amaurosis (LCA), a congenital retinopathy with pathological features bearing similarities to RP, 60 genes have now been implicated in disease etiology. If syndromic forms of disease and other hereditary retinopathies are included, 202 genetic loci have been identified and a total of 161 genes so far characterized. ${ }^{1} \mathrm{RP}$ segregates largely in an autosomal dominant, recessive, or X-linked recessive manner, ${ }^{2}$ whereas all of the 16 genetic forms of LCA that have been identified to date are autosomal recessive; hence, gene therapies require strategies based either on gene replacement, or on the selective suppression of dominantly mutated genes, or their transcripts. Progress is being made to the extent that clinical trials involving AAV-mediated gene replacement have now been established for one form of LCA caused by mutations within the RPE65 gene. ${ }^{3-5}$ In addition, therapeutic modalities have been demonstrated for other genetic subtypes of RP and LCA in a growing number of animal models, both of recessive and dominant forms of disease. ${ }^{6-23}$ Notwithstanding such progress, the genetic complexity of this group of diseases represents a formidable logistic and economic hurdle in developing viable methods of prevention. Given this caveat, parameters effecting photoreceptor survival that are independent of the primary genetic lesion are critically important to identify. It has emerged over the last 5 or so years that major pathological features involving sub-retinal drusen deposition and choroidal neovascularization that are associated with one form of multifactorial retinopathy, namely age-related macular degeneration, where the central cone-rich part of the retina, or macula, degenerates, can now be explained, at least in part, by excessive complement activity on ocular surfaces. ${ }^{24-30}$ However, the influence of complement on cone photoreceptor survival is less clear in hereditary (as opposed to multi-factorial) forms of retinal disease. Here we show that levels of $\mathrm{Clq}$, the primary component of the classical complement pathway, rise substantially in retinal tissues over the course of degeneration in mice induced by a targeted disruption of the rhodopsin gene, a model of autosomal recessive RP and that in the absence of $\mathrm{Clq}$ (Rho-l $-\mathrm{Clqa}-/-)$ cone photoreceptor function and viability are significantly compromised. We suggest that the protective effect observed here may relate to the role of $\mathrm{Clq}$ in clearance of apoptotic cells from the retina. These observations may assist in the development of strategies for optimal cone cell survival in such conditions.

\section{MATERIALS AND METHODS}

Mice

All experiments involving the use of mice were assessed and approved by an internal ethics committee at Trinity College Dublin. All studies carried out adhered to the ARVO statement for the use of animals in ophthalmic and vision research.

\section{Genotyping analysis}

Rho-/-, Clqa-/-, and C3-/- mice, on C57BL/6 backgrounds, were genotyped as follows. Rhodopsin: Oligo a (5'-TTCAAGCCCAAGCTTTC GCG-3') is a reverse primer for pol2:neo, and oligos b and c are forward and reverse primers for exon II of the rhodopsin gene (b, $5^{\prime}$-TCTCTCATG AGCCTAAAGCT-3'; c, 5'-ATGCCTGGAACCAATCCGAG-3'). C1qa: Oligo d $\left(5^{\prime}\right.$-GGGGATCGGCAATAAAAAGAC- $\left.3^{\prime}\right)$ is a primer in the $3^{\prime}$-end of the neomycin gene, and oligos $\mathrm{e}$ and $\mathrm{f}$ are forward and reverse primers for the Clqa gene (e, 5'-GGGGACCTGTGATCCAGACAG-3'; f, 5'-AAACCAT TGCCTCCAGGATGG-3'). C3: Oligo g (5'-AAGGGACTGGCTGCTATTGG-3') is a primer in the neomycin gene, and oligos $\mathrm{h}$ and $\mathrm{i}$ are forward and reverse primers for the C3 gene ( $h$, 5'-CTTCATAGACTGCTGCAACCA-3'; i, 5'-AACCAGCTCTGTGGGAAGTG-3'). Amplification reaction: $100 \mathrm{ng}$ DNA,

\footnotetext{
${ }^{1}$ The Ocular Genetics Unit, Smurfit Institute of Genetics, Trinity College Dublin, Dublin, Ireland; ${ }^{2}$ The Research Foundation, The Eye and Ear Hospital, Dublin, Ireland; ${ }^{3}$ Centre for Complement \& Inflammation Research, Department of Medicine, Imperial College, London, UK

*Correspondence: Dr MM Humphries, The Ocular Genetics Unit, Smurfit Institute of Genetics, Trinity College, Lincoln Place Gate, Dublin 2, Ireland. Tel: +00 35318962484 ; Fax: +00 3531896 3848; E-mail: mhumphri@tcd.ie

${ }^{4}$ These authors contributed equally to this work.

Received 1 March 2011; revised 1 July 2011; accepted 5 July 2011; published online 24 August 2011
} 
50 pmol of each oligonucleotide primer, $200 \mu \mathrm{m}$ each of dGTP, dATP, dCTP, and dTTP, $1.5 \mathrm{~mm} \mathrm{MgCl}_{2}$, and $1.25 \mu \mathrm{l}$ of GoTaq DNA Polymerase (Medical Supply Co. Ltd, Dublin, Ireland) in a total reaction volume of $50 \mu \mathrm{l}$. PCR conditions, $95^{\circ} \mathrm{C} 2 \mathrm{~min}\left(95^{\circ} \mathrm{C} 1 \mathrm{~min} ; 60^{\circ} \mathrm{C} 1 \mathrm{~min} ; 72^{\circ} \mathrm{C} 1 \mathrm{~min}\right)$ for 35 cycles, and a final extension of $72{ }^{\circ} \mathrm{C}$ for $5 \mathrm{~min}$. PCR products were resolved on a $1.5 \%$ agarose gel, fragments of 461 and $300 \mathrm{bp}, 360$ and $160 \mathrm{bp}$, and 920 and $1100 \mathrm{bp}$ being diagnostic of the wild-type and mutant alleles of the rhodopsin, Clqa, and $\mathrm{C} 3$ genes, respectively.

\section{Electroretinographic (ERG) analysis}

Three-month-old animals of genotypes Clqa-/-Rho-/-, C3-/-Rho-/-, and Rho-/- were dark-adapted overnight and prepared for ERG under dim red light. Pupillary dilation was carried out by instillation of $1 \%$ cyclopentalate, and $2.5 \%$ phenylephrine. Animals were anesthetized by intraperitoneal injection of ketamine ( $2.08 \mathrm{mg}$ per $15 \mathrm{~g}$ body weight) and xylazine $(0.21 \mathrm{mg}$ per $15 \mathrm{~g}$ body weight). The ERG commenced $10 \mathrm{~min}$ after administration of anesthetic. Standardized flashes of light were presented to the mouse in a Ganzfeld bowl to ensure uniform retinal illumination. The ERG responses were recorded simultaneously from both eyes by means of gold wire electrodes (Roland Consult, Brandenburg an der Havel, Germany) using Vidisic (Bausch \& Lomb, Dr. Mann Pharma, Berlin, Germany) as a conducting agent, and to maintain corneal hydration. The eye was maintained in a proptosed position throughout the examination by means of a small plastic band placed behind the globe. Reference and ground electrodes were positioned subcutaneously, approximately $1 \mathrm{~mm}$ from the temporal canthus and anterior to the tail, respectively. Body temperature was maintained at $37^{\circ} \mathrm{C}$ using a heating device controlled by a rectal temperature probe. Responses were analyzed using a RetiScan RetiPort electrophysiology unit (Roland Consult). The protocol was based on that approved by the International Clinical Standards Committee for human electroretinography. Cone-isolated responses were recorded using a white flash of intensity 3 candelas $/ \mathrm{m}^{2} / \mathrm{s}$ presented against a rod-suppressing background light of 30 candelas $/ \mathrm{m}^{2}$ to which the previously dark-adapted animal had been exposed for $10 \mathrm{~min}$ prior to stimulation. The responses to 48 individual flashes, presented at a frequency of $0.5 \mathrm{~Hz}$, were computer averaged. The a-waves were measured from the baseline to a-wave trough, and b-waves from the a-wave trough to the b-wave peak. ${ }^{31}$

\section{Immunohistochemical analysis of retinal cryosections}

Following euthanasia by means of $\mathrm{CO}_{2}$, eyes from mice were fixed in $4 \%$ paraformaldehyde, $\mathrm{pH}$ 7.4, for $4 \mathrm{~h}$, followed by three washes in PBS. Eyes were cryoprotected using a sucrose gradient, and subsequently embedded in optimum cutting temperature embedding compound (Lennox Ltd, Dublin, Ireland), and cryostat sections ( $12 \mu \mathrm{m})$ were cut onto amino-propyltriethoxysilane-coated glass slides. For cone staining, sections were blocked for $1 \mathrm{~h}$ with normal goat serum, and subsequently incubated with peanut agglutinin-Alexa568 (1:500, Invitrogen, Carlsbad, CA, USA) overnight at $4{ }^{\circ} \mathrm{C}$. Sections were washed three times with PBS, and counterstained with DAPI. For blue cone opsin staining, sections were air dried and blocked for $1 \mathrm{~h}$ in $5 \%$ donkey serum at room temperature. Sections were subsequently incubated with a polyclonal goat anti-blue sensitive opsin antibody (Santa Cruz Biotechnology, Santa Cruz, CA, USA) overnight at $4{ }^{\circ} \mathrm{C}$ (1:100 dilution in PBS containing $1 \%$ donkey serum). Following $3 \times 15 \mathrm{~min}$ washes with PBS, sections were incubated with a secondary antibody (goat anti-sheep IgG-Cy3 (red), Jackson ImmunoResearch Europe Ltd, Suffolk, UK) for $1 \mathrm{~h}$ at $37^{\circ} \mathrm{C}$. Nuclei were counterstained with DAPI (blue), and mounted using Aqua-Poly/Mount mounting medium (Polysciences Inc., Park Scientific Ltd, Northampton, UK). Analysis of stained sections was performed at room temperature with an Olympus FluoView TM FV1000 Confocal microscope with integrated software (Mason Technology, Dublin, Ireland).

Total RNA isolation from retinal tissues for quantitative real-time PCR analysis

Collected retinal tissues were frozen in liquid nitrogen and stored at $-80^{\circ} \mathrm{C}$. Total RNA was extracted from retinas of three mice per experimental group, using an RNeasy Mini Kit (Qiagen, Hilden, Germany) according to manufacturer's protocol. The level of Clqa transcript was quantified using Applied
Biosystems 7300 Real-Time PCR System (Life Technologies Corporation, Carlsbad, CA, USA), with Quantitect SYBR Green Kit (Qiagen) according to manufacturer's protocol. The following amplification conditions were used: $50{ }^{\circ} \mathrm{C}$ for $20 \mathrm{~min} ; 95^{\circ} \mathrm{C}$ for $15 \mathrm{~min} ; 37$ cycles of $95^{\circ} \mathrm{C}$ for $15 \mathrm{~s} ; 60^{\circ} \mathrm{C}$ for $1 \mathrm{~min}$. Dissociation steps included $95^{\circ} \mathrm{C}$ for $15 \mathrm{~s} ; 60^{\circ} \mathrm{C}$ for $1 \mathrm{~min} ; 95^{\circ} \mathrm{C}$ for $15 \mathrm{~s}$, and $60^{\circ} \mathrm{C}$ for $15 \mathrm{~s}$. Clqa mRNA levels were normalized to the corresponding $\beta$-actin level for each sample. HPLC-purified primers (Sigma-Aldrich Ireland Ltd, Arklow, Ireland) used for amplification were as follows: C1qa forward $5^{\prime}-\mathrm{A}$ TGGAGACCTCTCAGGGATG-3'; C1qa reverse 5'-ATACCAGTCCGGATGCC AGC-3'; $\beta$-actin forward $5^{\prime}$-TCACCCACACTGTGCCCATCTACGA-3'; $\beta$-actin reverse $5^{\prime}$-CAGCGGAACCGCTCATTGCCAATGG-3'. Experiments were repeated three times in triplicate, and for each time point, data are expressed as mean \pm SEM and analyzed using a two-tailed Student's $t$-test, with $P<0.05$ considered significant.

\section{RESULTS}

We crossed Rho $-/-{ }^{32}$ and Clqa $-/-$ mice $^{33}$ (both animals had been bred onto congenic C57BL/6 backgrounds). Rho-/- mice never develop normal rod outer segments, and lose their rods within 3 months. At that point, cones are still present, and approximately three rows of nuclei, including non-functional rods and remaining cones, are observable in the outer nuclear layer of the retina. ${ }^{34}$ Moreover, cone function is still readily detectable by ERG. ${ }^{35}$ Figure 1a shows typical cone ERGs from $\mathrm{C} 57 \mathrm{BL} / 6$ and $\mathrm{Clqa}-/-$ mice, indicating essentially no differences between these animals. The timing of the photopic b-wave in each tracing is essentially identical at circa $52 \mathrm{~ms}$ when animals were compared. The morphologies of the waveforms differ somewhat, mainly in the less prominent oscillatory potential on the upslope of the $\mathrm{Clqa}-/-$, but this variation is well within the range which is observed between individual animals. Similar variation, when observed in human patients, would not be of clinical significance. Left and right panels of Figure 1b, show cone responses from Rho-/- and $\mathrm{Clqa}-/-\mathrm{Rho}-/-$ mice, respectively, at 3 months. The reduction in amplitudes of cone b-wave in double knockout mice is strikingly apparent, compared with the Rho-/- genotype, and a direct reflection of a reduction in cone viability. A two-sample $t$-test comparison of b-wave amplitudes between C1qa-/-Rho-/- and Rho-/- mice showed a highly significant reduction in amplitudes in double knockouts $\left({ }^{*} P=0.0026\right.$; Figure $\left.1 \mathrm{c}\right)$.

We stained retinal cryosections from 3-month-old mice with peanut agglutinin, a lectin, which is specific for cone photoreceptors. The pattern and distribution of cone photoreceptors appeared decreased and more disordered in Clqa $-/-\mathrm{Rho}-/-$ retinas when compared with Rho- $/-$ retinas at 3 months of age (Figure 2a). Six out of seven Clqa-/-Rho-/- mice analyzed showed no immunoreactivity for blue cone opsin, whereas distinct staining was still observable in Rho-1- retinas at 3-month-old mice (Figure 2b).

Levels of C1qa transcript were analyzed by RT-PCR and were highly elevated in Rho- $/-$ retinas at 30 days, and this increase was observed up to, and including, 90 days old when compared with wild type mice (Figure $3 ; n=3$ mice per group and 3 replicate experiments).

We also examined cone viability and function in Rho- $/-$ mice with a targeted disruption of the $\mathrm{C} 3$ gene. ${ }^{36}$ We observed no statistical differences in cone ERG's between $\mathrm{C} 3-/-\mathrm{Rho}-/-$ and Rho-/animals (Figure 4).

\section{DISCUSSION}

Although significant progress is being made in the development of genebased medicines for degenerative retinopathies, the very high level of heterogeneity of these conditions at the genetic level is a major impediment to rapid progress. Although the human retina is rod-dominated, preservation of cone function is of primary significance, and in this 

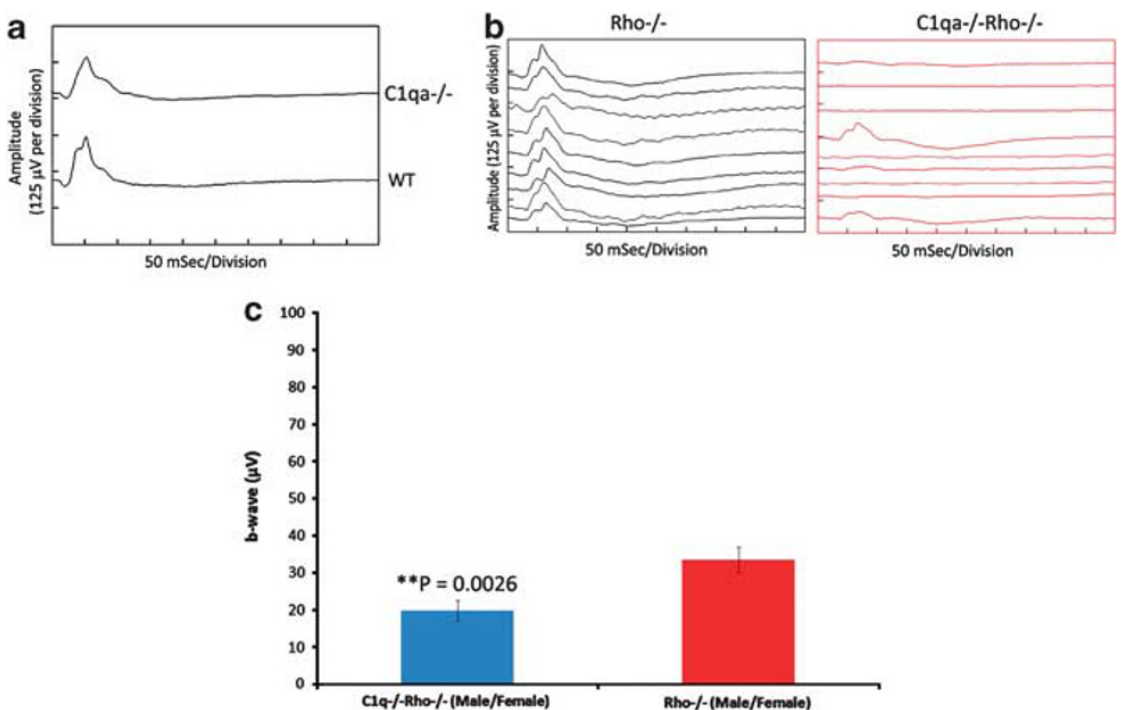

Figure 1 Cone ERG responses from wild-type (WT), Clqa-/-, Rho-/-, and Rho-/-Clqa-/- mice. The timing of the major positive deflection (the b-wave) is $52 \mathrm{~ms}$ in each tracing. (a) Cone ERG responses from C1qa-l- and WT mice at 12 weeks of age. (b) Cone ERG rsponses were still evident in Rho-/mice (left panel), with average readings of $33.48 \mu \mathrm{V}(n=55)$. However, in C1qa-/-Rho-/- mice (right panel), these readings were decreased to an average of $19.86 \mu \mathrm{V}$ at 12 weeks of age $(n=34)$. (c) The decrease in cone-isolated ERG was highly significant, with $* * P \leq 0.0026$. Cone ERG responses are representative of nine different animals per group.

a

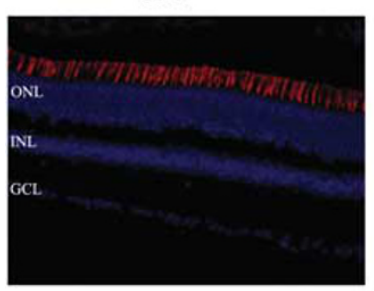

Rho-/-

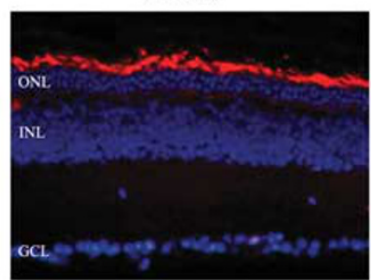

b

Rho-\%

C1qa-/-Rho-/-
WT
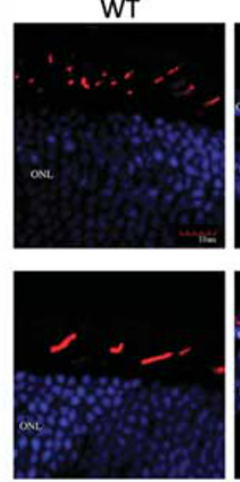

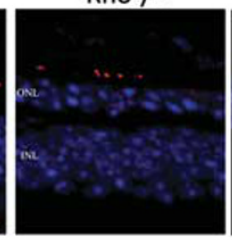

\section{Clqa-/-Rho-/-}

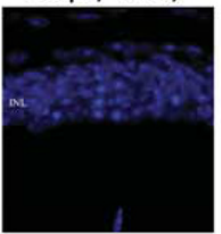

\section{Central region}
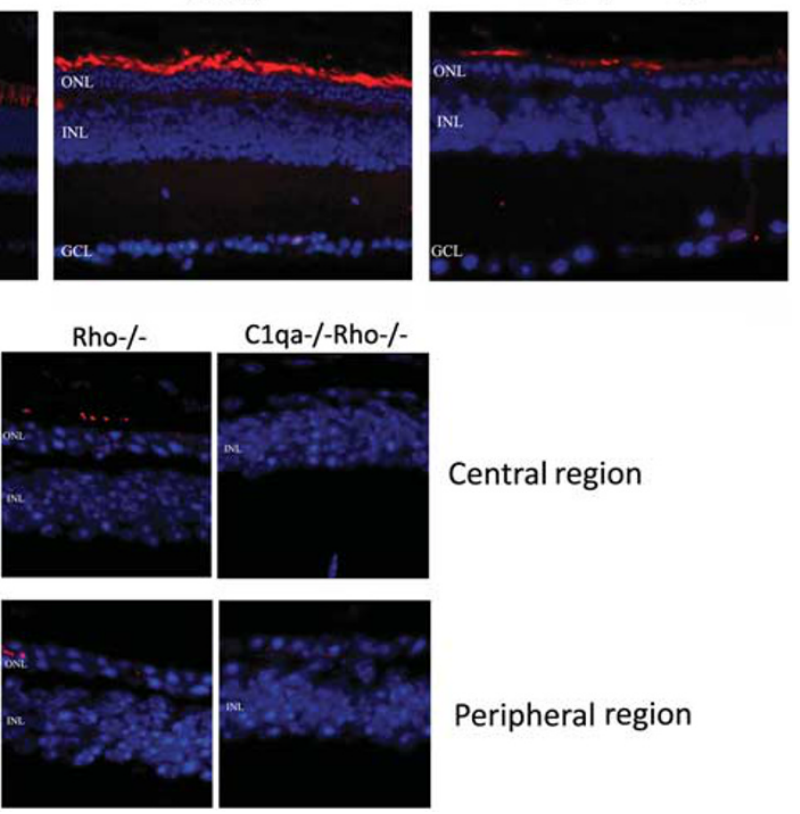

Peripheral region

Figure 2 Comparative retinal histology in WT, Rho-/-, and Rho-/-Clqa-/- mice. (a) The presence and pattern of cone photoreceptors were analyzed in WT, Rho-I-, and Clqa-/-Rho-/- mice. Although there was positive peanut agglutinin staining in Rho-I- and C1qa-/-Rho-/- mice at 12 weeks of age, the pattern and distribution of staining appeared radically different in Clqa-/-Rho-/- mice when compared with Rho-/- mice. (b) Retinal cryosections from 12-week-old mice were stained with an antibody specific for blue-sensitive opsin. Strong immunoreactivity was observed in the WT sections, staining blue cone photoreceptors in the central and peripheral aspects of the retina, and clearly showing the distribution of cone photoreceptors in the mouse retina (red: blue-sensitive opsin; blue: DAPI-nuclei). Although not as widespread, positive immunoreactivity for blue-sensitive opsin was also evident in Rho-/mice. However, in $\mathrm{Clqa}-/-\mathrm{Rho}-/-$ mice, strong immunoreactivity in cryosections for blue-sensitive opsin was not evident.

regard, a number of cone photoreceptor survival factors have been identified. In an extensive analysis of global transcriptional profiles in four murine retinopathy models, a high number of transcripts from genes encoding proteins of the insulin/mTOR signaling pathway were found to be upregulated, and these workers were able to show that systemic administration of insulin enhances cone photoreceptor survival. ${ }^{37}$
Although AAV-mediated expression of ciliary neurotrophic factor has been shown to result in significant cone cell loss in the $\mathrm{Rd} 2$ model of murine retinal degeneration, ${ }^{38}$ encapsulated release of this compound directly into the vitreous has been shown to be effective in preservation of vision in human subjects, and appears to be the only neuroprotective factor currently in clinical trial for treatment of degenerative retinopathies 


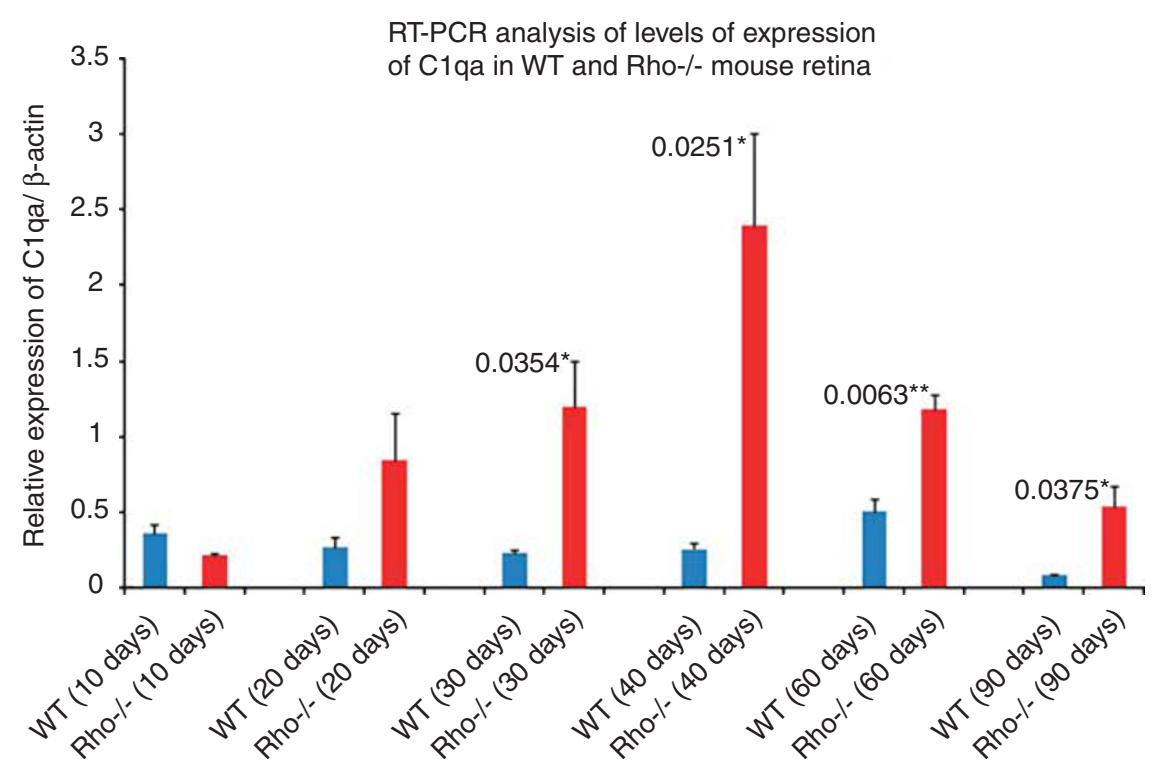

Figure 3 Quantitative analysis of levels of Clq transcript in normal and Rho-/- mice. Levels of C1qa transcript became significantly upregulated in the retinas of Rho-/- mice at 30 days when compared with WT mice of the same age. Upregulation continued up to and including 90 days ( $n=3$ mice per group, and results representative of three replicate experiments).

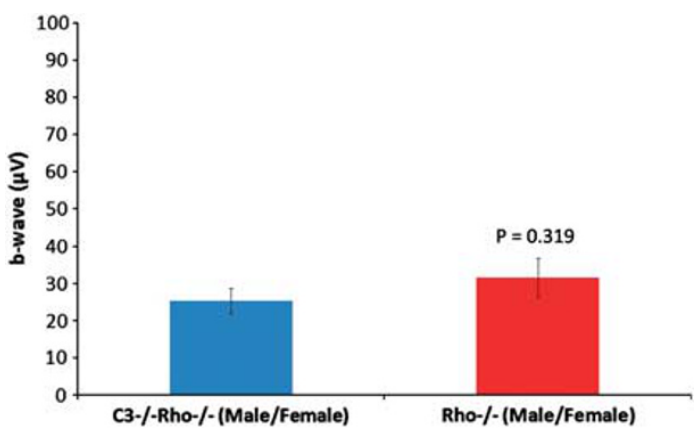

Figure 4 Statistical analysis of cone ERG responses from C3-/-Rho-/and Rho- $/$ - male and female mice at 3 months of age $(P=0.319 ; n=20$ per group). The data showed no significant differences between both groups of animals, indicating that cone photoreceptor function was essentially the same in both experimental cohorts. Data was analyzed as mean \pm SD with significance represented by $P<0.05$.

(http://www.neurotechusa.com/news_events/pr_2007-04-17.asp). ${ }^{39}$ Another cone cell survival factor showing substantial promise in slowing retinal degeneration is rod-derived cone viability factor. This protein is a member of the thioredoxin family, and has been shown to be protective against oxidative stress. ${ }^{40-42}$ Mice with a targeted disruption of the rod-derived cone viability factor gene (Nxnl1-/-) show enhanced loss of cone photoreceptor viability and function, ${ }^{43}$ and it has also been shown that sub-retinal inoculation of the purified protein results in a therapeutic effect. ${ }^{44}$ In regard to the neuroprotective effect exerted by C1q in the current study, this protein is a primary component of the classical complement pathway. Complement activity within the eye has been firmly associated with agerelated macular degeneration development, where anaphylatoxininduced induction of vascular endothelial growth factor may contribute to choroidal neovascularization, the major sight-threatening pathology associated with the exudative form of disease. ${ }^{45-47} \mathrm{Clq}$ is not, therefore, an immediately obvious neuroprotective candidate. However, this protein also binds to cells in the later phases of apoptosis, activating the classical complement pathway, with the resultant deposition onto such cells of complement components $\mathrm{C} 3$ and $\mathrm{C} 4$, facilitating phagocytosis. ${ }^{48-50}$

All evidence indicates that in degenerative retinopathies, photoreceptor death is apoptotic. ${ }^{51,52}$ We have shown here that levels of $\mathrm{Clq}$ progressively rise over the course of photoreceptor degeneration in the Rho-/- mouse model. Rho-/- mice lose all (up to one million) rods over 3 months, or, averaged out over this period of time, approximately 10000 photoreceptors per day by apoptosis. We suggest that appreciably higher levels of $\mathrm{Clq}$ in Rho-/- mice, as the disease progresses, represents a physiological response to optimally maintain apoptotic cell clearance, and in the absence of Clq, clearance is sub-optimal, favoring cell lysis, and hence, the induction of inflammatory processes which may negatively impact on disease pathology. In support of this hypothesis, we show that in the absence of $\mathrm{Clq}$, cone photoreceptor viability and function are significantly compromised. It is of interest to note that in an elegant study, Rohrer et $a l^{53}$ have recently reported that photoreceptor degeneration in the $\mathrm{rd} 1$ mouse, with a naturally occurring null mutation within the gene encoding the $\beta$-subunit of cyclic GMP phosphodiesterase, is unaffected in the absence of C1q. However, no ERG studies on cone cell function were reported in that study, and the rapidity of retinal degeneration in that model (complete photoreceptor loss within 3 weeks of birth) may have masked any more subtle effects in phenotype that may have been induced by the absence of C1q. In regard to strategies for cone cell preservation in degenerative hereditary retinopathies, data presented here suggest that optimal cone viability will be achieved by maintaining, or enhancing the expression of $\mathrm{Clq}$.

\section{CONFLICT OF INTEREST}

The authors declare no conflict of interest.

\section{ACKNOWLEDGEMENTS}

The Ocular Genetics Unit at TCD is supported by Science Foundation Ireland, Health Research Board of Ireland, EVI-Genoret (LSHG-CT-2005-512036) and Fighting Blindness Ireland. We would like to thank Ms Caroline Woods and Mr Charles Murray for animal husbandry. 
1 RetNet: The Retinal Information Network. http://www.sph.uth.tmc.edu/RetNet Stephen P Daiger, PhD, Administrator, The Univ. of Texas Health Science Center at Houston, 1996-present.

2 Heckenlively JR: Retinitis Pigmentosa. JB Lippincott: Philadelphia, PA, USA, 1988

3 Bainbridge JW, Smith AJ, Barker SS et al: Effect of gene therapy on visual function in Leber's congenital amaurosis. N Engl J Med 2008; 358: 2231-2239.

4 Maguire AM, Simonelli F, Pierce EA et al: Safety and efficacy of gene transfer for Leber's congenital amaurosis. N Engl J Med 2008; 358: 2240-2248.

5 Hauswirth WW, Aleman TS, Kaushal S et al: Treatment of leber congenital amaurosis due to RPE65 mutations by ocular subretinal injection of adeno-associated virus gene vector: short-term results of a phase I trial. Hum Gene Ther 2008; 19: 979-990.

6 Acland GM, Aguirre GD, Ray J et al: Gene therapy restores vision in a canine model of childhood blindness. Nat Genet 2001; 28: 92-95.

7 Smith AJ, Schlichtenbrede FC, Tschernutter M, Bainbridge JW, Thrasher AJ, Ali RR: AAV-mediated gene transfer slows photoreceptor loss in the RCS rat model of retinitis pigmentosa. Mol Ther 2003; 8: 188-195.

8 Tschernutter M, Schlichtenbrede FC, Howe S et al: Long-term preservation of retinal function in the RCS rat model of retinitis pigmentosa following lentivirus-mediated gene therapy. Mol Ther 2005; 12: 694-701.

9 Pawlyk BS, Smith AJ, Buch PK et al: Gene replacement therapy rescues photoreceptor degeneration in a murine model of Leber congenital amaurosis lacking RPGRIP. Invest Ophthalmol Vis Sci 2005; 46: 3039-3045.

10 Kiang AS, Palfi A, Ader $\mathrm{M}$ et al: Toward a gene therapy for dominant disease: validation of an RNA interference-based mutation-independent approach. Mol Ther 2005; 12: $555-561$.

11 Min SH, Molday LL, Seeliger MW et al: Prolonged recovery of retinal structure/function after gene therapy in an Rs1h-deficient mouse model of $\mathrm{x}$-linked juvenile retinoschisis. Mol Ther 2005; 2: 644-651.

12 Jacobson SG, Acland GM, Aguirre GD et al: Safety of recombinant adeno-associated virus type 2-RPE65 vector delivered by ocular subretinal injection. Mol Ther 2006; 13 : 1074-1084.

13 Hashimoto T, Gibbs D, Lillo C et al: Lentiviral gene replacement therapy of retinas in a mouse model for Usher syndrome type 1B. Gene Ther 2007; 14: 584-594.

14 Alexander JJ, Umino Y, Everhart D et al: Restoration of cone vision in a mouse model of achromatopsia. Nat Med 2007; 13: 685-687.

15 O'Reilly M, Palfi A, Chadderton N et al: RNA interference-mediated suppression and replacement of human rhodopsin in vivo. Am J Hum Genet 2007; 81: 127-135.

16 Kong J, Kim SR, Binley $\mathrm{K}$ et al: Correction of the disease phenotype in the mouse model of Stargardt disease by lentiviral gene therapy. Gene Ther 2008; 15: 1311-1320.

17 Pang JJ, Boye SL, Kumar A et al: AAV-mediated gene therapy for retinal degeneration in the rd10 mouse containing a recessive PDEbeta mutation. Invest Ophthalmol Vis Sci 2008; 49: 4278-4283.

18 Tam LC, Kiang AS, Kennan A et al: Therapeutic benefit derived from RNAi-mediated ablation of IMPDH1 transcripts in a murine model of autosomal dominant retinitis pigmentosa (RP10). Hum Mol Genet 2008; 17: 2084-2100.

19 Tan MH, Smith AJ, Pawlyk B et al: Gene therapy for retinitis pigmentosa and Leber congenital amaurosis caused by defects in AIPL1: effective rescue of mouse models of partial and complete Aipl1 deficiency using AAV2/2 and AAV2/8 vectors. Hum $\mathrm{Mol}$ Genet 2009; 18: 2099-2114.

20 Sun $\mathrm{X}$, Pawlyk $\mathrm{B}, \mathrm{Xu} \mathrm{X}$ et al: Gene therapy with a promoter targeting both rods and cones rescues retinal degeneration caused by AIPL1 mutations. Gene Ther 2009; 17 : 117-131.

21 Komáromy AM, Alexander JJ, Rowlan JS et al: Gene therapy rescues cone function in congenital achromatopsia. Hum Mol Genet 2010; 19: 2581-2593.

22 Tam LC, Kiang AS, Campbell M et al: Prevention of autosomal dominant retinitis pigmentosa by systemic drug therapy targeting heat shock protein 90 (Hsp90). Hum Mol Genet 2010; 19: 4421-4436.

$23 \mathrm{Li} \mathrm{X,} \mathrm{Li} \mathrm{W,} \mathrm{Dai} \mathrm{X} \mathrm{et} \mathrm{al:} \mathrm{Gene} \mathrm{therapy} \mathrm{rescues} \mathrm{cone} \mathrm{structure} \mathrm{and} \mathrm{function} \mathrm{in} \mathrm{the}$ 3-month-old rd12 mouse: a model for midcourse RPE65 leber congenital amaurosis. Invest Ophthalmol Vis Sci 2011; 52: 7-15.

24 Edwards AO, Malek G: Molecular genetics of AMD and current animal models. Angiogenesis 2007; 10: 119-132.

25 Yates JRW, Sepp T, Baljinder KM et al: Complement C3 variant and the risk of agerelated macular degeneration. N Engl J Med 2007; 357: 19-27.

26 Maller JB, Fagerness JA, Reynolds RC, Neale BM, Daly MJ, Seddon JM: Variation in complement factor 3 is associated with risk of age-related macular degeneration. Nat Genet 2007; 39: 1200-1201.
27 Haines JL: C3 R102G polymorphism increased risk of age-related macular degeneration. Hum Mol Genet 2008; 17: 1821-1824.

28 Schultz DW, Klein ML, Humpert AJ et al: Analysis of the ARMD1 locus: evidence that a mutation in HEMICENTIN-1 is associated with age-related macular degeneration in a large family. Hum Mol Genet 2003; 12: 3315-3323.

29 Stone EM, Braun TA, Russell SR et al: Missense variations in the fibulin 5 gene and age-related macular degeneration. N Engl J Med 2004; 351: 346-353.

30 Canter JA, Olson LM, Spencer K et al: Mitochondrial DNA polymorphism A4917G is independently associated with age-related macular degeneration. PLOS ONE 2008; 3: e2091.

31 Marmor M, Cabael L, Shukla S, Hwang JC, Marcus M: Clinical S-cone ERG recording with a commercial hand-held full-field stimulator. Doc Ophthalmol 2004; 108: 107-114.

32 Humphries MM, Rancourt D, Farrar GJ et al: Retinopathy induced in mice by targeted disruption of the rhodopsin gene. Nat Genet 1997; 15: 216-219.

33 Botto M, Dell'Agnola C, Bygrave AE et al: Homozygous C1q deficiency causes glomerulonephritis associated with multiple apoptotic bodies. Nat Genet 1998; 19 : 56-59.

34 Humphries MM, Kiang A-S, McNally $\mathrm{N}$ et al: Comparative structural and functional analysis of photoreceptor neurons of Rho-/ - mice reveal increased survival on C57BL $6 \mathrm{~J}$ in comparison to $129 \mathrm{~Sv}$ genetic background. Vis Neurosci 2001; 18: 437-443.

35 Toda K, Bush RA, Humphries P, Sieving PA: The electroretinogram of the rhodopsin knockout mouse. Vis Neurosci 1999; 16: 391-398.

36 Baruah P, Simpson E, Dumitriu IE et al: Mice lacking C1q or C3 show accelerated rejection of minor $\mathrm{H}$ disparate skin grafts and resistance to induction of tolerance. Eur $\mathrm{J}$ Immunol 2010; 40: 1758-1767.

37 Punzo C, Kornacker K, Cepko CL: Stimulation of the insulin/mTOR pathway delays cone death in a mouse model of retinitis pigmentosa. Nat Neurosci 2009; 12: 44-52.

38 Schlichtenbrede FC, MacNeil A, Bainbridge JW et al: Intraocular gene delivery of ciliary neurotrophic factor results in significant loss of retinal function in normal mice and in the Prph2Rd2/Rd2 model of retinal degeneration. Gene Ther 2003; 10 : 523-527.

39 Talcott KE, Ratnam K, Sundquist SM et al: Longitudinal study of cone photoreceptors during retinal degeneration and in response to ciliary neurotrophic factor treatment. Invest Ophthalmol Vis Sci 2011; 52: 2219-2226.

40 Mohand-Said S, Deudon-Combe A, Hicks D et al: Normal retina releases a diffusible factor stimulating cone survival in the retinal degeneration mouse. Proc Natl Acad Sci USA 1998; 95: 8357-8362.

41 Fintz AC, Audo I, Hicks D, Mohand-Said S, Léveillard T, Sahel J: Partial characterization of retina-derived cone neuroprotection in two culture models of photoreceptor degeneration. Invest Ophthalmol Vis Sci 2003; 44: 818-825.

42 Léveillard T, Sahel JA: Rod-derived cone viability factor for treating blinding diseases: from clinic to redox signaling. Sci Transl Med 2010; 2: $26 \mathrm{ps} 16$.

43 Cronin T, Raffelsberger W, Lee-Rivera I et al: The disruption of the rod-derived cone viability gene leads to photoreceptor dysfunction and susceptibility to oxidative stress. Cell Death Differ 2010; 17: 1199-1210.

44 Yang Y, Mohand-Said S, Danan A et al: Functional cone rescue by RdCVF protein in a dominant model of retinitis pigmentosa. Mol Ther 2009; 17: 787-795.

45 Klein RJ, Zeiss $\mathrm{C}$, Chew EY et al: Complement factor $\mathrm{H}$ polymorphism in age-related macular degeneration. Science 2005; 308: 363-364.

46 Edwards AO, Ritter R, Abel KJ, Manning A, Panhuysen C, Farrer LA: Complement factor $\mathrm{H}$ polymorphism and age-related macular degeneration. Science 2005; 308 . 421-424.

47 Haines JL, Hauser MA, Schmidt S et al: Complement factor $\mathrm{H}$ variant increases the risk of age-related macular degeneration. Science 2005; 308: 419-421.

48 Navratil JS, Watkins SC, Wisnieski JJ, Ahearn JM: The globular heads of C1q specifically recognize surface blebs of apoptotic vascular endothelial cells. J Immunol 2001; 166: 3231-3239.

49 Trouw LA, Blom AM, Gasgue P: Role of complement and complement regulators in the removal of apoptotic cells. Mol Immunol 2008; 45: 1199-1207.

50 Nauta AJ, Trouw LA, Daha MR et al: Direct binding of C1q to apoptotic cells and cell blebs induces complement activation. Eur J Immunol 2002; 32: 1726-1736.

51 Portera-Cailliau C, Sung CH, Nathans J, Adler R: Apoptotic photoreceptor cell death in mouse models of retinitis pigmentosa. Proc Natl Acad Sci USA 1994; 91: 974-978.

52 Sunaief JL, Dentchev T, Ying GS, Milam AH: The role of apoptosis is age-related macular degeneration. Arch Ophthalmol 2002; 120: 1435-1442.

53 Rohrer B, Demos C, Frigg R, Grimm C: Classical complement activation and acquired immune response pathways are not essential for retinal degeneration in the rd1 mouse. Exp Eye Res 2007; 84: 82-91. 